\title{
24. LATE QUATERNARY STABLE ISOTOPE RECORD OF BENTHIC FORAMINIFERS: SITES 805 AND 806, ONTONG JAVA PLATEAU ${ }^{1}$
}

\author{
T. Bickert, ${ }^{2}$ W.H. Berger, ${ }^{3}$ S. Burke, ${ }^{3}$ H. Schmidt,${ }^{3}$ and G. Wefer ${ }^{2}$
}

\begin{abstract}
We present oxygen and carbon isotope records for benthic foraminifers from Ocean Drilling Program Sites 805 and 806 for the last $650,000 \mathrm{yr}$. Comparison of these records (Cibicidoides wuellerstorfi) with similar records from elsewhere shows that they are of excellent quality. The oxygen isotope patterns provide no evidence for substantial deep-water cooling in the western equatorial Pacific during glacial times (in contrast to the eastern Pacific and to the deep Atlantic). The carbon isotope record largely reflects global patterns and is influenced by the changing production rate of NADW (as evidenced in Pacific-Atlantic $\delta^{13 C}$ differences). Changes in planktonic-benthic $\delta^{13} \mathrm{C}$ differences in these records provide support for increased productivity during glacial periods in the western equatorial Pacific, in agreement with other evidence.
\end{abstract}

\section{INTRODUCTION}

Considerable evidence exists that major changes took place in deep-water circulation in the late Pleistocene on a glacial-interglacial time scale (e.g., Curry and Lohmann, 1983; Shackleton et al., 1983b; Keigwin, 1987; Curry et al., 1988; Duplessy et al., 1988; Keir, 1988; Oppo and Fairbanks, 1990). Such changes have implications for the dynamics of heat transport, for geochemical budgets in the ocean, and for atmospheric $\mathrm{CO}_{2}$ content. The deep Pacific Ocean, because of its great mass and uniformity, serves as a reference base in paleoceanographic reconstructions (Shackleton and Opdyke, 1973; Shackleton and Pisias, 1985; Oppo and Fairbanks, 1987, 1990).

The Ontong Java Plateau in the western equatorial Pacific is especially well suited for the purpose of recovering a reference record. The plateau is a large elevated area in the western Pacific that bears a thick cover of calcareous ooze. Ocean Drilling Program (ODP) Sites 805 and 806 are close to the equator, at depths of 3188 and $2520 \mathrm{~m}$, respectively (Fig. 1). At these depths, the Ontong Java Plateau is bathed in Pacific Deep Water (Craig et al., 1981). Primary productivity in the area of these sites is but moderately elevated at this western end of the equatorial divergence (Berger et al., 1987a). Thus, the stable isotope records presented here should have a strong global component, little affected by equatorial upwelling and far from the influence of ocean margins.

The present study examines the oxygen and carbon isotope records of Sites 805 and 806 for the last $650,000 \mathrm{yr}$. We document the stable isotope record of Cibicidoides wuellerstorfi $(=$ Planulina wueller storfi) and compare it with similar records from elsewhere, and also with planktonic isotopes, to obtain clues for oceanic changes that occurred during the late Pleistocene.

\section{METHODS AND MATERIALS}

Holes $805 \mathrm{C}$ and $806 \mathrm{~B}$ were sampled at $10-\mathrm{cm}$ intervals from 0 to 10 and from 0 to $14 \mathrm{~m}$ below seafloor (mbsf), respectively. Sample preparation is described by Schmidt et al. (this volume). Carbon and oxygen isotopes were measured on the epibenthic species Cibicidoides wuellerstorfi, picked from the size fraction $>250 \mu \mathrm{m}$.

\footnotetext{
'Berger, W.H., Kroenke, L.W., Mayer, L.A., et al., 1993. Proc. ODP, Sci. Results, 130: College Station, TX (Ocean Drilling Program).

${ }^{2}$ Fachbereich Geowissenschaften, Universităt Bremen, Postfach 330440, D-2800 Bremen 33, Federal Republic of Germany.

${ }^{3}$ Geological Research Division, Scripps Institution of Oceanography, University of California, San Diego, La Jolla, CA 92093, U.S.A
}

Measurements were made at Bremen University on a Finnigan MAT 251 mass spectrometer. The samples were reacted with $100 \%$ phosphoric acid at $75^{\circ} \mathrm{C}$ in a Finnigan automatic carbonate preparation device system. Calibration to the international Pee Dee belemnite (PDB) scale was done through the U.S. National Institute of Standards and Technology carbonate standards NBS 18, 19, and 20. Long-term reproducibility $( \pm 1 \sigma)$ for $\delta^{18} \mathrm{O}$ and $\delta^{13} \mathrm{C}$ over $1 \mathrm{yr}$ is $0.07 \%$ and $0.05 \%$, respectively, for a calcite standard from Bavaria (Solnhofen limestone). The isotope data for Globigerinoides sacculifer for Sites 805 and 806 are taken from Schmidt et al. (this volume).

For comparison to the deep Atlantic, we chose the benthic record of Core GeoB 1105-4 from the eastern equatorial Atlantic, representing the modern North Atlantic Deep Water (NADW) (Table 1). These data also are based on analyzing $C$. wuellerstorfi. They were generated at Bremen University (T. Bickert, unpubl. data). Additional data for comparison are taken from Shackleton and Pisias (1985), who gave isotope data for Uvigerina senticosa from Core V19-30, eastern tropical Pacific. Their $\delta^{18} \mathrm{O}$ values were adjusted to those of $C$. wuellerstorfi by subtracting $0.64 \%$ (see Shackleton and Opdyke, 1973).

\section{ISOTOPE DATA AND STRATIGRAPHIC CONTROL}

The raw data for $C$. wuellerstorfi for Holes $805 \mathrm{C}$ and $806 \mathrm{~B}$ are plotted in Figure 2 and listed in Appendix A. The $\delta^{18} \mathrm{O}$ and $\delta^{13} \mathrm{C}$ records from the two holes are similar and also resemble the benthic records from other equatorial Pacific cores (Shackleton and Opdyke, 1973; Shackleton and Pisias, 1985; Shackleton and Hall, 1989). The record of Hole 806B appears to be undisturbed, except for small gaps at the core breaks (core $1 / 2=0.16 \mathrm{~m}$, core $2 / 3=0.74 \mathrm{~m}$; see Berger et al., this volume). Outlier values at 8.59 mbsf correspond to an anomalously high peak in the sand fraction (Yasuda et al., this volume), probably indicating a small turbidite at this level. In Hole $805 \mathrm{C}$, a hiatus seems to be present at $7.5 \mathrm{mbsf}$, leaving a gap between oxygen isotope stages 12.4 and 14.2, which corresponds to the time interval between 471 and 538 k.y.

Oxygen isotope records of both holes were correlated by peak-topeak correlation to the stacked isotope record given by Imbrie et al. (1984). The resulting chronology (Appendix B) was compared with the age model by Berger et al. (this volume), which is based on tuning to obliquity cycles ( $41 \mathrm{k.y}$.). The differences between these two age models are illustrated by juxtaposing the respective sedimentation rates obtained (Fig. 3).

The overall agreement between the two approaches is quite good and validates the methods (Fig. 3). However, clearly much more variability is present in the sedimentation rate record based on peak- 

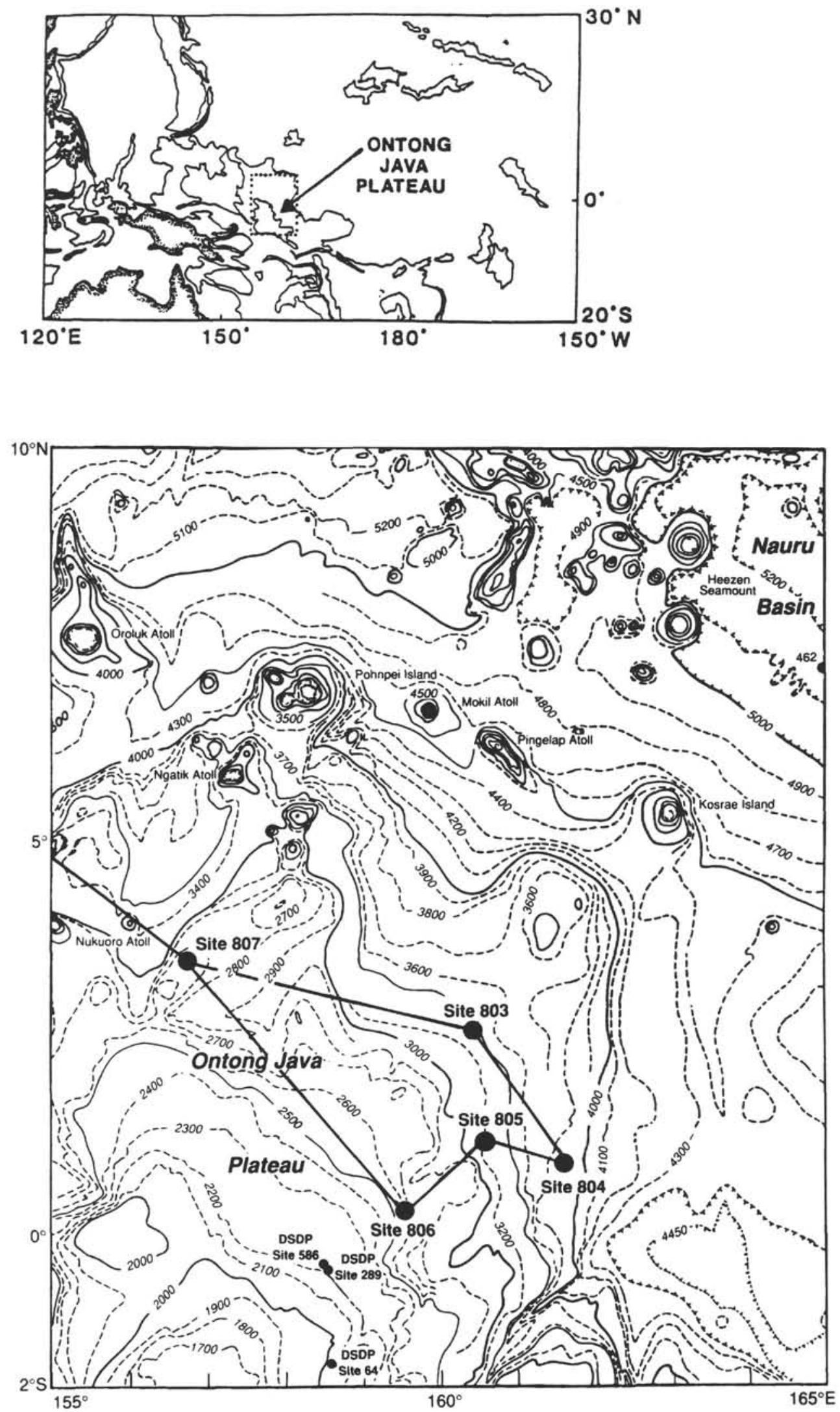

Figure 1. Location of Sites 805 and 806 (from Kroenke, Berger, Janecek, et al., 1991). 
Table 1. Locations and water depths of the cored sites presented or discussed in the text.

\begin{tabular}{lccc}
\hline \multicolumn{1}{c}{ Site } & Latitude & Longitude & $\begin{array}{c}\text { Water depth } \\
(\mathrm{m})\end{array}$ \\
\hline ODP 805C & $1^{\circ} 13.7^{\prime} \mathrm{N}$ & $160^{\circ} 31.8^{\prime} \mathrm{E}$ & 3188 \\
ODP 806B & $0^{\circ} 19.1^{\prime} \mathrm{N}$ & $159^{\circ} 21.7^{\prime} \mathrm{E}$ & 2520 \\
V19-30 & $3^{\circ} 21^{\prime} \mathrm{S}$ & $83^{\circ} 21^{\prime} \mathrm{W}$ & 3091 \\
GeoB 1105-4 & $1^{\circ} 39.9^{\prime} \mathrm{S}$ & $12^{\circ} 25.7^{\prime} \mathrm{W}$ & 3225 \\
\hline
\end{tabular}

to-peak correlation than in that derived from tuning to obliquity. The resolution of age modeling by tilt cycles is restricted to one-half of a cycle of obliquity ( 20.5 k.y.). The control ages of a reference stack, in principle, is limited only by the number of age control points available (in this case, dated peaks) and by the scale of benthic mixing (a few thousand years). It should be kept in mind that the amplitude of variability of the sedimentation rate allowed by the tuning method is limited by the width of the band-pass filter around the 41-k.y. period. In the present case, this restricts variations to roughly $\pm 20 \%$ from the average sedimentation rate. Peak-to-peak correlation, on the other hand, is susceptible to errors both from the original age assignments in the reference section and from artificial peak shifts caused by discrete sampling. The difference in age between the two chronologies is at most 13.5 k.y. at any one depth level.

The mean sedimentation rates over the interval studied are 15 $\mathrm{m} / \mathrm{m}$.y. (Site 805 ) and $22 \mathrm{~m} / \mathrm{m}$.y. (Site 806 ). This is only about one-half of the rates observed in eastern equatorial cores at corresponding depths (Shackleton and Pisias, 1985; Shackleton and Hall, 1989). The difference between east and west reflects the higher supply of biogenic carbonates in the eastern tropical Pacific, which is the result of an approximately 2-3 times higher productivity (Berger et al., 1987a). Sediments at Sites 805 and 806 consist of almost pure foraminiferal nannofossil ooze containing only a small admixture of siliceous components. The carbonate content for both holes is about $83 \%-87 \%$.

Site 806 is located well above the present depth of the foraminiferal lysocline in this region, whereas Site 805 is quite close to that level (3400 m; Berger et al., 1982). Thus, much of the difference in sedimentation rate between the two sites (Fig. 4) presumably is related to the effects of carbonate dissolution, including removal by processes related to solifluction and resuspension, rather than chemical dissolution alone (Berger et al., 1991). The large fluctuations in dissolution intensity observed for the late Quaternary in this region (Hebbeln et al., 1990; Grötsch et al., 1991; Wu et al., 1991) should bear measurably on short-term fluctuations in sedimentation rate in Site 805. In addition to effects from carbonate dissolution, however, changes in productivity also must be considered. A decrease in sedimentation rates occurs away from the equatorial high-productivity zone (Berger and Killingley, 1982), which might provide for a somewhat lower sedimentation rate at Site 805 , located about $1^{\circ}$ farther south from the equator than Site 806 .

\section{OXYGEN ISOTOPES: RESULTS AND DISCUSSION}

The records of $\delta^{18} \mathrm{O}$ changes in C. wuellerstorfi for Sites 805 and 806 (Fig. 5) closely resemble previously published benthic records. The difference in $\delta^{18} \mathrm{O}$ values between the two sites is typically $0.15 \%$ (Fig. 6). This corresponds roughly to the expected delta- $\delta^{18} \mathrm{O}$ for modern equilibrium values, attributable to the slightly lower temperature (and higher salinity) at the deeper site (Table 2). The "core top" values (Table 2) were estimated (rather than observed) because during coring within the drill string the surface sediment is commonly disturbed. Calculations are based on the paleotemperature equation of Epstein et al. (1953) as modified by Craig and Shackleton (see Birchfield, 1987). The relationship between salinity and $\delta^{18} \mathrm{O}$ was taken from Zahn and Mix (1991). This latter effect, in essence, is negligible in our case. The calculated "core top" values are in good agreement to the
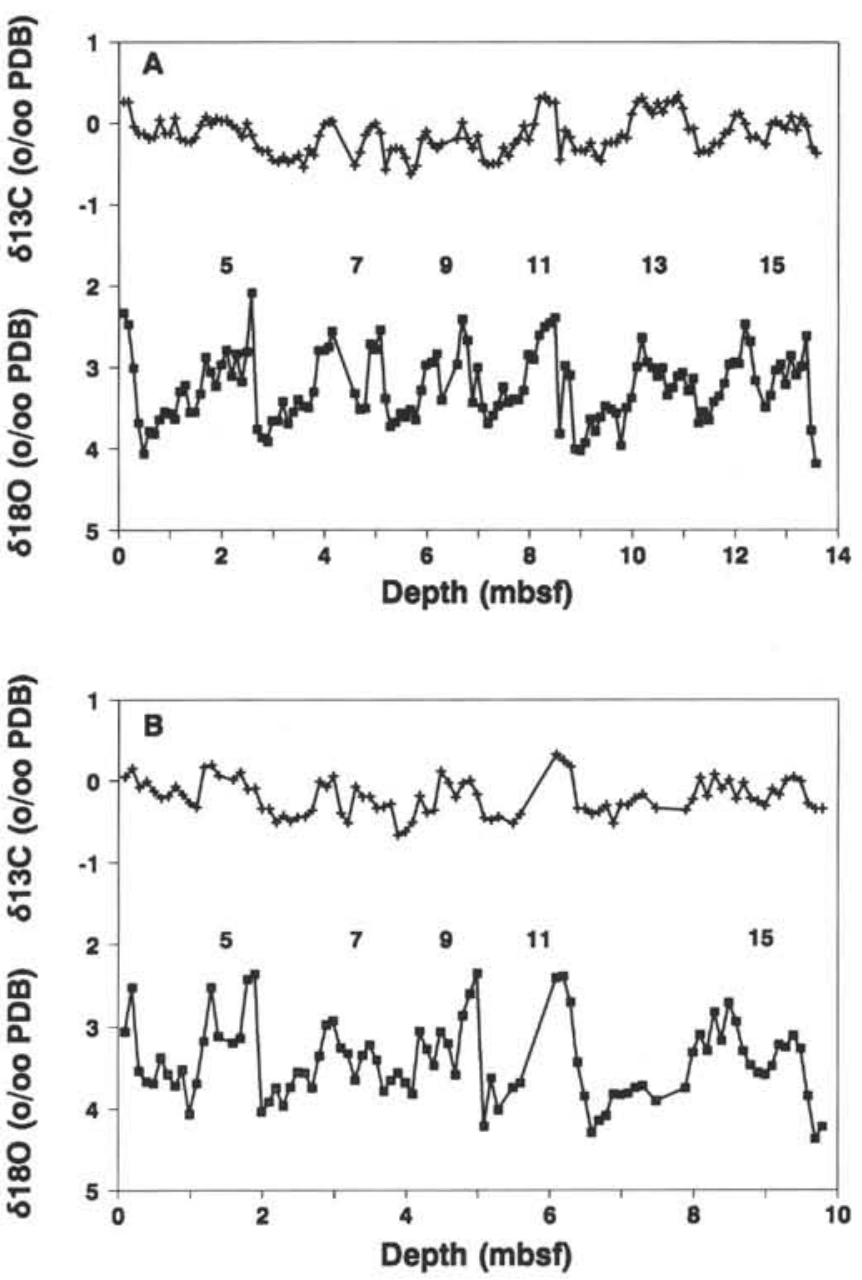

Figure 2. Carbon and oxygen isotope records of $C$. wuellerstorfi for Holes $806 \mathrm{~B}$ (A) and 805C (B).

actual box core surface values on Ontong Java Plateau, as given in Vincent et al. (1981) (see also Herguera et al., 1991).

The last glacial maximum (LGM) value for Hole 806B (Table 2) coincides with values reported from other records from the Pacific (Shackleton and Opdyke, 1973; Keigwin and Boyle, 1985; Duplessy et al., 1988). A glacial-to-interglacial difference in $\delta^{18} \mathrm{O}$ of $1.3 \%$ is indicated. This value is close to the shift ascribed to changes in ice volume on this time scale (ca. 1.3\% ; see Berger and Gardner, 1975; Berger et al., 1987b; Fairbanks, 1989). Thus, the limited evidence available to us does not call for a substantial deep-water cooling during glacial times in the western equatorial Pacific, and the cooling of $1.1^{\circ} \mathrm{C}$ reported by Birchfield (1987) would seem to represent an upper limit (cf. Herguera et al., 1991). In comparison, the oxygen isotope records from the eastern Pacific (Core V19-30) and the eastern equatorial Atlantic (Core GeoB 1105-4) show significantly greater $\mathrm{LGM}$ values. Assuming that salinity-related changes in $\delta^{18} \mathrm{O}$ can be neglected, glacial decreases in temperature of $0.8^{\circ} \mathrm{C}$ for the eastern Pacific and of $1.7^{\circ} \mathrm{C}$ for the Atlantic are indicated.

The modern NADW is about $1.5^{\circ} \mathrm{C}$ warmer than the present Pacific Deep Water (PDW). Thus, the greater cooling in the deep Atlantic may be ascribed to reduced advection of NADW during glacial times (see Curry and Lohmann, 1983; Shackleton et al., 1983b; Duplessy et al., 1988; Oppo and Fairbanks, 1990). Further back in time (Fig. 7), the oxygen isotope record in the Atlantic (Core GeoB $1105-4$ ) closely tracks to the Hole $806 \mathrm{~B}$ record in interglacial stages, but it shows generally heavier values in glacial times. The eastern Pacific record (Core V19-30; Uvigerina, adjusted), in contrast, shows 


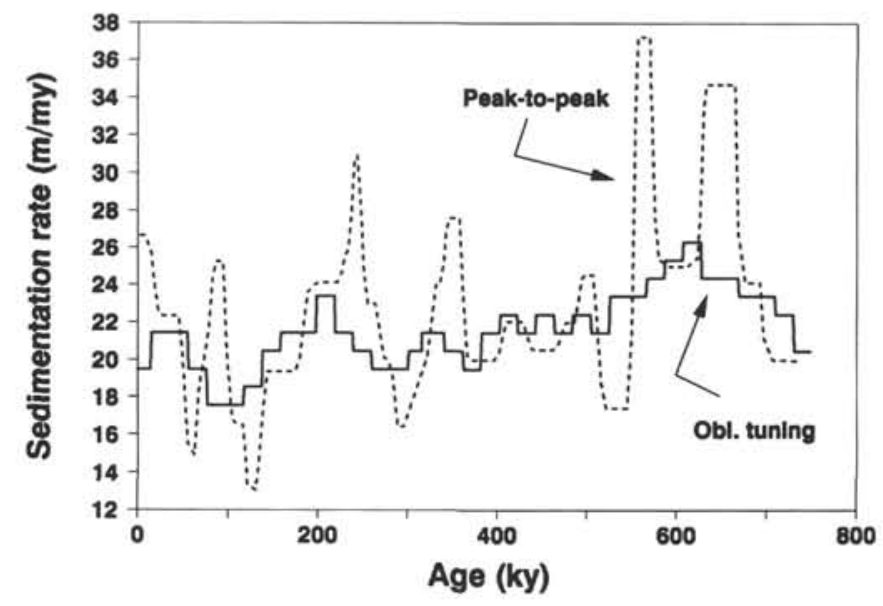

Figure 3. Comparison of sedimentation rates for Hole $806 \mathrm{~B}$ from peak correlation and obliquity tuning.

a constant difference of about $0.3 \%$ to its western counterpart, probably caused by the difference in water depth (see Table 1) or by an incomplete correction of disequilibrium between the two measured foraminiferal species.

\section{CARBON ISOTOPES: RESULTS AND DISCUSSION}

The carbon isotope records of $C$. wuellerstorfi for Holes $805 \mathrm{C}$ and $806 \mathrm{~B}$ (Fig. 2) suggest that periods of low $\delta^{13} \mathrm{C}$ tend to correspond to periods of high $\delta^{18} \mathrm{O}$, and vice versa. The magnitude of glacial to interglacial changes in $\delta^{13} \mathrm{C}$ has an average of $0.7 \%$ over the interval studied, with a maximum of $0.9 \%$ at the Stage 11 to 12 transition. For the last 150 k.y., however, the difference between glacial and interglacial values is typically near $0.45 \%$, which corresponds to the change in the ocean's average carbon isotopic composition between the present and the LGM (e.g., Shackleton and Pisias, 1985). This difference is thought to result from a decrease in continental biomass caused by the presence of ice sheets from increased continental aridity (Shackleton, 1977; Keigwin and Boyle, 1985), and from the release, during times of lowered sea level, of organic matter stored on continental shelves (Broecker, 1981; Keir and Berger, 1983).

But why does an increase in $\delta^{13} \mathrm{C}$ amplitude occur further back in time? Keigwin and Boyle (1985) proposed that the precession of the Earth's rotational axis is responsible for the variations in low-latitude biomass. Thus, the higher amplitude of the carbon isotope signal before $150 \mathrm{k} . \mathrm{y}$. would be the result of an increased amplitude in the precession parameter. The precessional signal in the benthic record of Hole $806 \mathrm{~B}$, obtained by summing the Fourier terms corresponding to periods between 18 to 28 k.y., shows fair agreement with the precession index (Fig. 8A). Indeed, an increase in amplitude of precessional signals (both the astronomic one and the one in the sediment) is indicated from the present back to about 200 k.y.; however, the maximum for the observed differences in glacial to interglacial $\delta^{13} \mathrm{C}$ values occurs exactly where the amplitude of the precession is at a minimum: between 360 and $430 \mathrm{k}$.y. Thus, the power of the precessional effects seems insufficient to explain changes in glacial-to-interglacial amplitudes in benthic $\delta^{13} \mathrm{C}$ in our data. Further support for this conclusion can be derived from comparing the eccentricity index (the envelope to the precession index) with the eccentricity-related signal in the benthic record, obtained by summing the Fourier terms between 83 and 111 k.y. (Fig. 8B). One can see that neither precession nor eccentricity can account for the amplitude variation in the $\delta^{13} \mathrm{C}$ record of Hole 806B.

In addition to short-term variations, a long-term cyclic "drift" also occurs in the carbon isotope record, with a period of about 500 k.y. and an amplitude of 0.35\% (Fig. 8B). Shackleton (1985) suggested

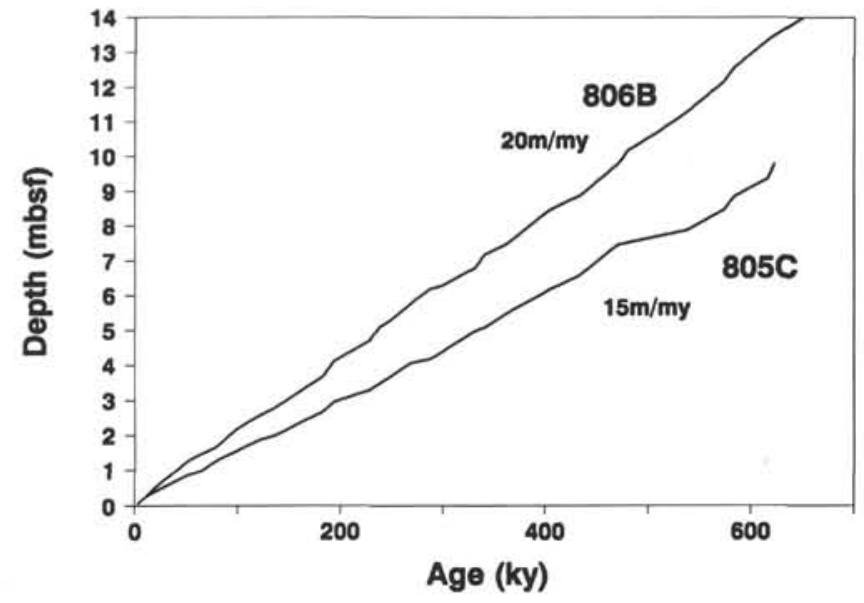

Figure 4. Age-depth plot for Holes 805C and 806B.

that this long-period cycle is a result of long-term changes in the proportion of carbon stored as organic carbon relative to that stored as carbonate.

A general correlation exists between climate and biomass, as seen in the covariance between the $\delta^{18} \mathrm{O}$ and $\delta^{13} \mathrm{C}$ data (Fig. 9). For the last $150 \mathrm{k} . \mathrm{y}$., the decrease in amplitude of $\delta^{13} \mathrm{C}$ fluctuation, as described previously, occurs simultaneously with greater variation in the $\delta^{18} \mathrm{O}$ signal (squares and regression line, Fig. 9). Thus, the nature of the correlation of $\delta^{18} \mathrm{O}$ and $\delta^{13} \mathrm{C}$ changes through time, suggesting nonlinear coupling of the two variables.

\section{ATLANTIC-PACIFIC COMPARISON}

In the modern ocean, values of $\delta^{13} \mathrm{C}$ of NADW are high for the deep-ocean environment ( $>1 \%$; Kroopnick, 1985). The reason is that NADW is "young"; that is, it contains a large amount of water that was recently at the surface and was enriched with ${ }^{13} \mathrm{C}$ as a result of isotopic fractionation by marine algae (e.g., Berger and Vincent, 1986). Values of $\delta^{13} \mathrm{C}$ of NADW decrease southward as the water ages and as it mixes with northward-spreading Circumpolar Deep Water (CDW) above and below, water characterized by low $\delta^{13} \mathrm{C}$ values $(0.4 \%)$ ). A branch of the CDW also is a source for PDW. On its path northward, $\mathrm{PDW}$ is depleted in ${ }^{13} \mathrm{C}$ because of the oxidation of ${ }^{13} \mathrm{C}$-poor organic matter (to about $0.1 \%$ at Site 806 ; see Kroopnick, 1985).

For comparison of the deep Atlantic carbon isotope record with that of the deep Pacific, we again use Core GeoB 1105-4 (Fig. 7), situated within the NADW water-mass layer. The Atlantic $\delta^{13} \mathrm{C}$ record has a much greater variability than the Pacific one (Fig. 10). The maximum amplitude of the difference between the records is about $0.8 \%$ (Fig. 10, upper curve). Apparently, the Core GeoB 1105-4 record cannot be taken as a typical NADW signal, however. Evidence from comparisons with other equatorial Atlantic records (Curry and Lohmann, 1983) suggests that the glacial $\delta^{13} \mathrm{C}$ values of this site are affected by pore-water effects resulting from high productivity in surface waters, similar to the carbon isotope values of endobenthic foraminiferal species. These effects lower the $\delta^{13} \mathrm{C}$ values by about $0.4 \%$ (Sarnthein et al., 1988) on average. Nevertheless, the Atlantic $\delta^{13} \mathrm{C}$ values always remain higher relative to those of the Pacific site (Fig. 10). Thus, basin-to-basin nutrient fractionation between the Atlantic and Pacific has existed throughout the late Pleistocene, being strong during interglacials and weakened during glacials (cf. Shackleton et al., 1983a; Boyle and Keigwin, 1986). The instances of zero difference (top curve in Fig. 10) should be read as $+0.4 \%$ to correct for the pore-water effect mentioned.

On the whole, greater $\delta^{13} \mathrm{C}$ differences tend to correspond to greater delta- $\delta^{18} \mathrm{O}$ values, and vice versa (Fig. 11). However, in detail 


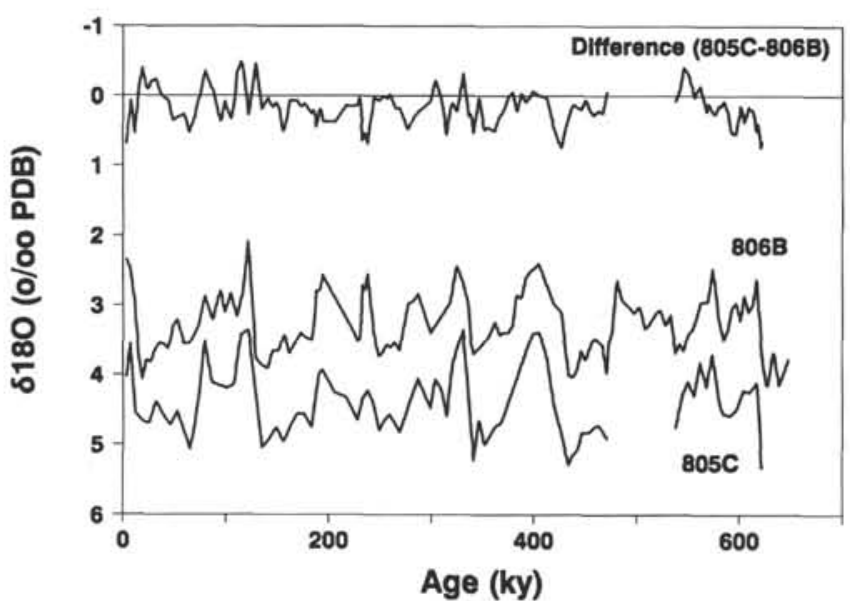

Figure $5 . \delta^{18} \mathrm{O}$ records of $C$. wuellerstorfi for Holes $806 \mathrm{~B}$ and $805 \mathrm{C}(+1.0 \%$ for clarity) and their difference.

the Atlantic-to-Pacific $\delta^{18} \mathrm{O}$ and $\delta^{13} \mathrm{C}$ differences are not closely correlated in a simple fashion. The production of NADW is correlated, on theoretical grounds, with atmospheric $\mathrm{pCO}_{2}$ (Keir, 1988). However, considerable discrepancies exist between the record of $\delta^{13} \mathrm{C}$ differences and the $\mathrm{pCO}_{2}$ record given by Barnola et al. (1987). We shall not pursue this matter further here.

\section{PLANKTONIC VS. BENTHIC $\delta^{13}$ C RECORDS}

The $\delta^{13} \mathrm{C}$ records for $G$. sacculifer and $C$. wuellerstorfi in Hole $806 \mathrm{~B}$ (measured on the same samples) are similar to some extent (Fig. 12). The benthic-to-planktonic $\delta^{13} \mathrm{C}$ differences show no trend at all, indicating that the long-term drift cycle in the benthic record (Fig. 8) is present in the planktonic record as well. In general, a greater $\delta^{13} \mathrm{C}$ difference is present in glacial than in interglacial times, suggesting stronger biologic pumping of organic carbon in glacial times. At the same time, overall $\delta^{13} \mathrm{C}$ values tend to be more negative during these periods. The amplitude of the delta- $\delta^{13} \mathrm{C}$ record reaches a maximum in Stage 10. The relationship between delta- $\delta^{13} \mathrm{C}(C$. wuellerstorfi-G. sacculifer $)$ and $\delta^{18} \mathrm{O}(G$. sacculifer $)$ is not exactly the same for the two Ontong Java sites studied here (Fig. 13). For the same heavy $\delta^{18} \mathrm{O}$ values (glacials), delta- $\delta^{13} \mathrm{C}$ values are somewhat lighter at Site 806 than at Site 805, whereas the interglacial differences for the two sites are about the same. As pointed out previously, no significant difference exists between the benthic $\delta^{13} \mathrm{C}$ records of the two holes. Perhaps the slight differences seen in the delta- $\delta^{13} \mathrm{C}$ patterns can be attributed either to the effects of dissolution (Wu and Berger, 1991) or to subtle differences in upwelling patterns between Site 806 (on the equator) and Site 805 (off the equator).

If the mean nutrient content of the deep ocean was greater during glacial periods than during interglacials, higher surface productivity would have reduced atmospheric $\mathrm{CO}_{2}$ (Broecker, 1981). An overall increase in nutrients would have resulted in higher surface water $\delta^{13} \mathrm{C}$ relative to the $\delta^{13} \mathrm{C}$ of deep water. Given this scenario, the planktonicbenthic $\delta^{13} \mathrm{C}$ differences, a measure of the strength of the "biological pump," should match the atmospheric $\mathrm{CO}_{2}$ record (Shackleton et al., 1983b; Berger et al., 1989). Indeed, a general resemblance exists between the $\delta^{13} \mathrm{C}$ difference curve and the $\mathrm{pCO}_{2}$ record (Fig. 14). However, discrepancies are present in the detail, suggesting that the delta- $\delta^{13} \mathrm{C}$ record is not a reliable proxy for $\mathrm{pCO}_{2}$. In any case, on theoretical grounds and based on observations, changes in surfacewater productivity cannot be taken as the only important (or even the most important) control on atmospheric $\mathrm{pCO}_{2}$ in the late Quaternary. Rather, several mechanisms must be invoked, including the alkalinity of the ocean (Keir and Berger, 1983; Curry and Crowley, 1987; Boyle, 1988; Keir, 1988).

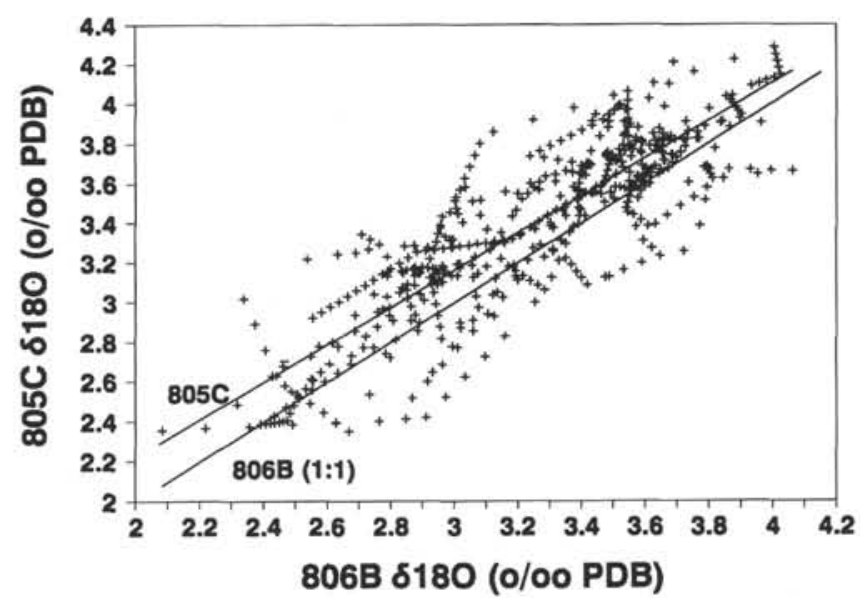

Figure 6. Plot of age-equivalent $\delta^{18} \mathrm{O}$ values from Holes $806 \mathrm{~B}$ and $805 \mathrm{C}$ (based on peak-to-peak correlation).

Table 2. Modern oceanographic data, recent and last glacial maximum benthic $\delta^{18} \mathrm{C}$ values, and temperatures.

\begin{tabular}{lllllll}
\hline & \multicolumn{4}{c}{ Modern } & & \multicolumn{2}{c}{ Last glacial maximum } \\
\cline { 2 - 4 } \cline { 7 - 7 } \multicolumn{1}{c}{ Site } & $\mathrm{T}\left({ }^{\circ} \mathrm{C}\right)$ & $\mathrm{S}(\%)$ & $\delta^{18} \mathrm{O}\left(\%_{0}\right)$ & & $\delta^{18} \mathrm{O}\left(\%_{0}\right)$ & $\mathrm{T}\left({ }^{\circ} \mathrm{C}\right)$ \\
\hline ODP 805C & 1.3 & 34.69 & 2.89 (calculated) & & 4.21 (estimated) & 1.2 \\
ODP 806B & 1.6 & 34.67 & 2.77 (calculated) & & 4.06 & 1.6 \\
V19-30 & 1.4 & 34.68 & 2.84 & & 4.38 & 0.6 \\
GeoB 1105 & 2.8 & 34.87 & 2.75 & & 4.51 & 1.1 \\
\hline
\end{tabular}

Notes: $\delta^{18} \mathrm{O}$ of $\mathrm{V} 19-30$ adjusted by $-0.64 \%$ (from $U$. senticosa to $C$. wuellerstorfi values).

\section{SUMMARY AND CONCLUSIONS}

The benthic stable isotope records at Sites 805 and 806 are of excellent quality and can serve as reference stratigraphies for paleoceanographic studies in the deep-water realm. Interference from productivity effects at this western end of the equatorial upwelling system seems to be moderate to negligible.

The oxygen isotope patterns provide no evidence for substantial deep-water cooling at this location in glacial times, in contrast to published findings for the eastern Pacific and the deep Atlantic. The benthic $\delta^{13} \mathrm{C}$ record largely reflects the global average range. No correlation exists between the variations in amplitude of $\delta^{13} \mathrm{C}$ and the precessional cycle, or eccentricity variation. Significant fluctuation is present in the differences in $\delta^{13} \mathrm{C}$ values between the deep Atlantic and the deep Pacific, as a result of variations in the production of NADW.

Changes in planktonic-benthic $\delta^{13} \mathrm{C}$ differences suggest increased productivity during glacial times in the western equatorial Pacific, in agreement with other evidence (Herguera and Berger, 1991). This difference in $\delta 13 \mathrm{C}$, to some degree, can be used as a proxy for atmospheric $\mathrm{CO}_{2}$ fluctuations (Fig. 14). The exact relationship between proxy and target variable is complex and is not resolved. A number of different variables have to be considered for that purpose (e.g., Keir, 1988). Nevertheless, of these proxies, $\delta^{13} \mathrm{C}$ in foraminifers is probably the most important.

\section{ACKNOWLEDGMENTS}

We thank the members of the shipboard party of Leg 130 for assistance in sampling and other help rendered during the cruise. Dr. M. Segl, Bremen, supervised and facilitated the generation of the isotope data. P. Loubere and J.D. Wright reviewed the manuscript and made useful comments. This study was supported by grants from the Deutsche Forschungsgemeinschaft, and the U.S. National Science Foundation. 


\section{REFERENCES*}

Barnola, J.M., Raynaud, M.D., Korotkevich, Y.S., and Lorius, C., 1987. Vostok ice core provides 160,000-year record of atmospheric $\mathrm{CO}_{2}$. Nature, 329: 408-414.

Berger, W.H., Bonneau, M.-C., and Parker, F.L., 1982. Foraminifera on the deep-sea floor: lysocline and dissolution rate. Oceanol. Acta, 5:249-258.

Berger, W.H., Fischer, K., Lai, C., and Wu, G., 1987a. Ocean productivity and organic carbon flux. Part I: Overview and maps of primary production and export production. Univ. of California, San Diego, SIO Reference, 87-30.

Berger, W.H., and Gardner, J.V., 1975. On the determination of Pleistocene temperatures from planktonic foraminifera. J. Foraminiferal Res., 5:102-113.

Berger, W.H., and Killingley, J.S., 1982. Box cores from the equatorial Pacific; ${ }^{14} \mathrm{C}$ sedimentation rates and benthic mixing. Mar. Geol., 45:93-125.

Berger, W.H., Killingley, J.S., and Vincent, E., 1987b. Time scale of Wiscon$\sin /$ Holocene transition: oxygen isotope record in the western equatorial Pacific. Quat. Res., 28:295-306.

Berger, W.H., Kroenke, L.W., Mayer, L.A., and Shipboard Scientific Party, 1991. Ontong Java Plateau, Leg 130: synopsis of major drilling results. In Kroenke, L.W., Berger, W.H., Janecek, T.R., et al., Proc. ODP, Init. Repts., 130: College Station, TX (Ocean Drilling Program), 497-537.

Berger, W.H., Smetacek, V.S., and Wefer, G., 1989. Ocean productivity and paleoproductivity - an overview. In Berger, W.H., Smetacek, V.S., and Wefer, G. (Eds.), Productivity of the Ocean: Present and Past: Chichester (Wiley), 1-34.

Berger, W.H., and Vincent, E., 1986. Deep-sea carbonates: reading the carbon isotope signal. Geol. Rundsch., 75:249-269.

Birchfield, G.E., 1987. Changes in deep-ocean water $\delta^{18} \mathrm{O}$ and temperature from the last glacial maximum to the present. Paleoceanography, 2:431-442.

Boyle, E.A., 1988. The role of vertical chemical fractionation in controlling late Quaternary atmospheric carbon dioxide. J. Geophys. Res., 93:15701-15714.

Boyle, E.A., and Keigwin, L.D., 1986. Comparison of Atlantic and Pacific records for the last 215,000 years: changes in deep ocean circulation and chemical inventories. Earth Planet. Sci. Lett., 76:135-150.

Broecker, W.S., 1981. Glacial to interglacial changes in ocean and atmosphere chemistry. In Berger, A. (Ed)., Climate Variations and Variability: Facts and Theories: Hingham, MA (D. Reidel), 111-121.

Craig, H., Broecker, W.S., and Spencer, D., 1981. GEOSECS Pacific Expedition (Vol. 3): Washington (U.S. Govt. Printing Office).

Curry, W.B., and Crowley, T.J., 1987. The $\delta^{13} \mathrm{C}$ of equatorial Atlantic surface water masses: implications for ice age $\mathrm{pCO}_{2}$ levels. Paleoceanography, 2:489-517.

Curry, W.B., Duplessy, J.C., Labeyrie, L.D., and Shackleton, N.J., 1988. Changes in the distribution of $\delta^{13} \mathrm{C}$ of deep-water $\mathrm{\Sigma CO}_{2}$ between the last glaciation and the Holocene. Paleoceanography, 3:317-342.

Curry, W.B., and Lohmann, G.P., 1983. Reduced advection into Atlantic Ocean deep eastern basins during the last glacial maximum. Nature, 306:577-580.

Duplessy, J.C., Shackleton, N.J., Fairbanks, R.G., Labeyrie, L., Oppo, D., Kallel, N., 1988. Deep-water source variations during the last climatic cycle and their impact on the global deep-water circulation. Paleoceanography, 3:343-360.

Epstein, S., Buchsbaum, R., Lowenstam, H.A., and Urey, H.C., 1953. Revised carbonate-water isotopic temperature scale. Geol. Soc. Am. Bull., 64:1315-1325.

Fairbanks, R.G., 1989. A 17,000-year glacio-eustatic sea level record: influence of glacial melting rates on the Younger Dryas event and deep-ocean circulation. Nature, 342:637-642.

Grötsch, J., Wu, G., and Berger, W.H., 1991. Carbonate cycles in the Pacific: reconstruction of saturation fluctuations. In Einsele, G., Ricken, W. and Seilacher, A. (Eds.), Cycles and Events in Stratigraphy: Heidelberg (Springer-Verlag), 110-125.

Hebbeln, D., Wefer, G., and Berger, W.H., 1990. Pleistocene dissolution fluctuations from apparent depth of deposition in Core ERDC-127P, westequatorial Pacific. Mar. Geol., 92:165-176.

Herguera, J.C., and Berger, W.H., 1991. Paleoproductivity: glacial to postglacial change in the western equatorial Pacific, from benthic foraminifera. Geology, 19:1173-1176.

Herguera, J.C., Stott, L.D., and Berger, W.H., 1991. Glacial deep-water properties in the west-equatorial Pacific: bathyal thermocline near a depth of 2000 m. Mar. Geol., 100:201-206.

* Abbreviations for names of organizations and publication titles in ODP reference lists follow the style given in Chemical Abstracts Service Source Index (published by American Chemical Society).
Imbrie, J.,Hays, J.D., Martinson, D.G., McIntyre, A., Mix, A., Morley, J.J.,Pisias, N., Prell, W., and Shackleton, N.J., 1984. The orbital theory of Pleistocene climate: support from a revised chronology of the marine $\delta^{18} \mathrm{O}$ record. In Berger, A., Imbrie, J., Hays, J., Kukla, G., and Saltzman, B. (Eds.). Milankovitch and Climate (Pt. 1): Hingham, MA (D. Reidel), 269-305.

Keigwin, L.D., 1987. North Pacific deep-water formation during latest glaciation. Nature, 330:362-364.

Keigwin, L.D., and Boyle, E.A., 1985. Carbon isotopes in deep-sea benthic foraminifera: Precession and changes in low-latitude biomass. In Sundquist, E.T., and Broecker, W.S. (Eds.), The Carbon Cycle and Atmospheric $\mathrm{CO}_{2}$ Natural Variations Archean to Present. Am. Geophys. Union, 303-318.

Keir, R.S., 1988. On the Late Pleistocene ocean geochemistry and circulation. Paleoceanography, 3:413-445.

Keir, R.S., and Berger, W.H., 1983. Atmospheric $\mathrm{CO}_{2}$ content in the last 120,000 years: the phosphate-extraction model. J. Geophys. Res., 88:6027-6038.

Kroenke, L.W., Berger, W.H., Janecek, T.R., et al., 1991. Proc. ODP, Init. Repts., 130: College Station, TX (Ocean Drilling Program).

Kroopnick, P., 1985. The distribution of carbon-13 in the world oceans. Deep-Sea Res., Pt. A, 32:57-84.

Oppo, D.W., and Fairbanks, R.G., 1987. Variability in the deep and intermediate water circulation of the Atlantic Ocean: Northern Hemisphere modulation of the Southern Ocean. Earth Planet. Sci. Lett., 86:1-15.

, R.G., 1990. Atlantic ocean thermohaline circulation of the last 150,000 years: relationship to climate and atmospheric $\mathrm{CO}_{2}$. Paleoceanography, 5:277-288.

Sarnthein, M., Winn, K., Duplessy, J.C., and Fontugne, M.R., 1988. Global variations of surface ocean productivity in low and mid latitudes: influence on $\mathrm{CO}_{2}$ reservoirs of the deep ocean and atmosphere during the last 21,000 years. Paleoceanography, 3:361-399.

Shackleton, N.J., 1977. Tropical rain forest history and the equatorial Pacific carbonate dissolution cycles. In Anderson, N.R., and Malahoff, A. (Eds.), Fate of Fossil Fuel $\mathrm{CO}_{2}$ in the Oceans: New York (Plenum), 401-427.

1985. Oceanic carbon isotope constraints on oxygen and carbon dioxide in the Cenozoic atmosphere. In Sundquist, E.T., and Broecker, W.S. (Eds.), The Carbon Cycle and Atmospheric $\mathrm{CO}_{2}$ : Natural Variations Archean to Present. Am. Geophys. Union, 412-418.

Shackleton, N.J., and Hall, M.A., 1989. Stable isotope history of the Pleistocene at ODP Site 677. In Becker, K., Sakai, H., et al., Proc, ODP, Sci. Results, 111: College Station, TX (Ocean Drilling Program), 295-316.

Shackleton, N.J., Hall, M.A., Line, J., and Chuxi, C., 1983a. Carbon isotope data in Core V19-30 confirm reduced carbon dioxide in the ice age atmosphere. Nature, 306:319-322.

Shackleton, N.J., Imbrie, J., and Hall, M., 1983b. Oxygen and carbon isotope record of east Pacific Core V19-30: implications for the formation of deep-water in the Late Pleistocene North Atlantic. Earth Planet. Sci. Lett. 65:233-266.

Shackleton, N.J., and Opdyke, N.D., 1973. Oxygen isotope and paleomagnetic stratigraphy of equatorial Pacific Core V 28-238: oxygen isotope temperatures and ice volumes on a 105 year scale. Quat. Res., 3:39-55.

Shackleton, N.J., and Pisias, N.G., 1985. Atmospheric carbon dioxide, orbital forcing, and climate. In Sundquist, E.T., and Broecker, W.S. (Eds.), The Carbon Cycle and Atmospheric $\mathrm{CO}_{2}$ : Natural Variations Archean to Present. Am. Geophys. Union, Geophys. Monogr., 32:303-318.

Vincent, E., Killingley, J.S., and Berger, W.H., 1981. Stable isotope composition of benthic foraminifera from the equatorial Pacific. Nature, 289:639-643.

Wu, G., and Berger, W.H., 1991. Pleistocene $\delta^{18} \mathrm{O}$ record from Ontong Java Plateau: effects of winnowing and dissolution. Mar. Geol., 96:193-209.

Wu, G., Yasuda, M.K., and Berger, W.H., 1991. Late Pleistocene carbonate stratigraphy on Ontong Java Plateau in the western equatorial Pacific. Mar. Geol., 99:135-150.

Zahn, R., and Mix, A.C., 1991. Benthic foraminiferal $\delta^{18} \mathrm{O}$ in the ocean's temperature-salinity-density field: Constraints on ice age thermohaline circulation. Paleoceanography, 6:1-20.

Date of initial receipt: 4 November 1991

Date of acceptance: 1 September 1992

Ms 130B-025 


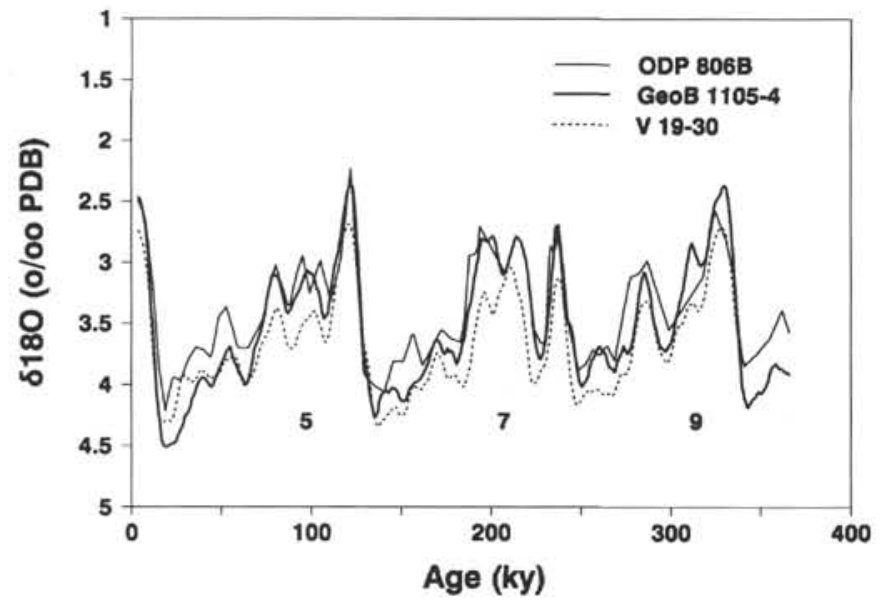

Figure 7. Comparison of the benthic $\delta^{18} \mathrm{O}$ records of ODP Hole 806B, Core V19-30, and Core GeoB 1105-4. Hole 806B values have been increased by $0.15 \%$ to conform to those of Hole $805 \mathrm{C}$ at the greater water depths; Core V19-30 values are adjusted by $-0.64 \%$ (from $U$. senticosa to $C$. wuellerstorfi).
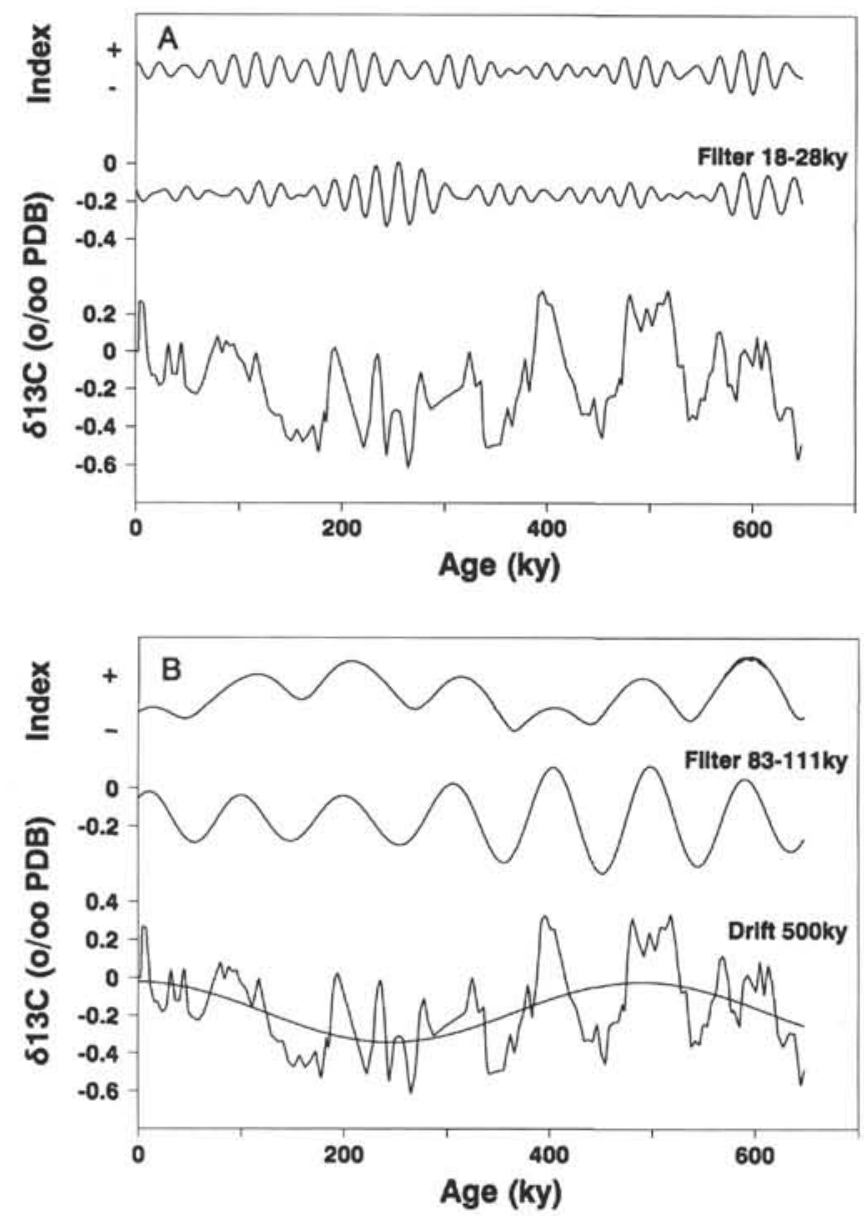

Figure 8. Hole 806B benthic $\delta^{13} \mathrm{C}$ data compared to $(\mathbf{A})$ precession index and frequency-filtered data and to (B) eccentricity index, frequency-filtered data, and 500-k.y. drift.

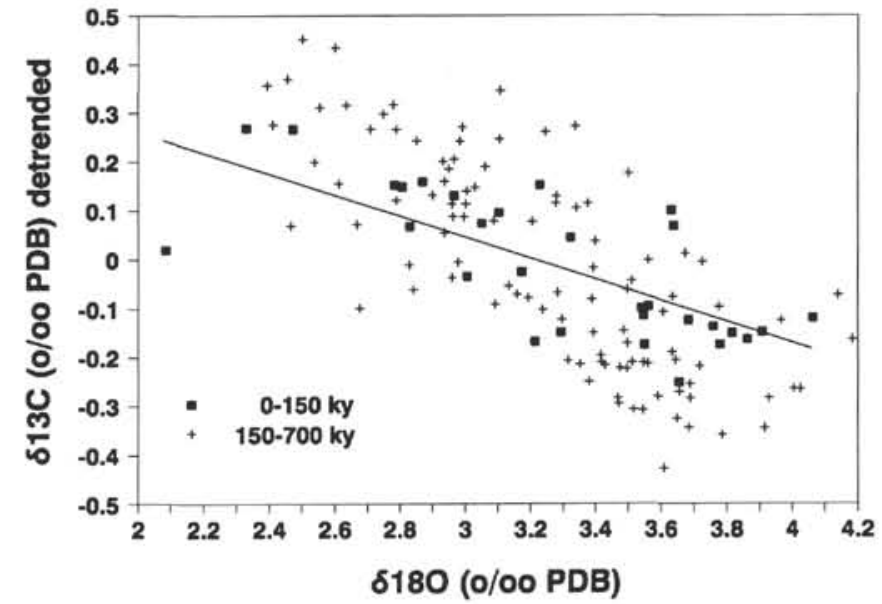

Figure 9. Covariance of $\delta^{18} \mathrm{O}$ and $\delta^{13} \mathrm{C}$ values for C.wuellerstorfi in Hole 806B $\left(\delta^{13} \mathrm{C}\right.$ values detrended for the $500-k$.y. drift). Data points are grouped by $0-150$ k.y. (solid squares and regression line) and $>150$ k.y. (crosses).

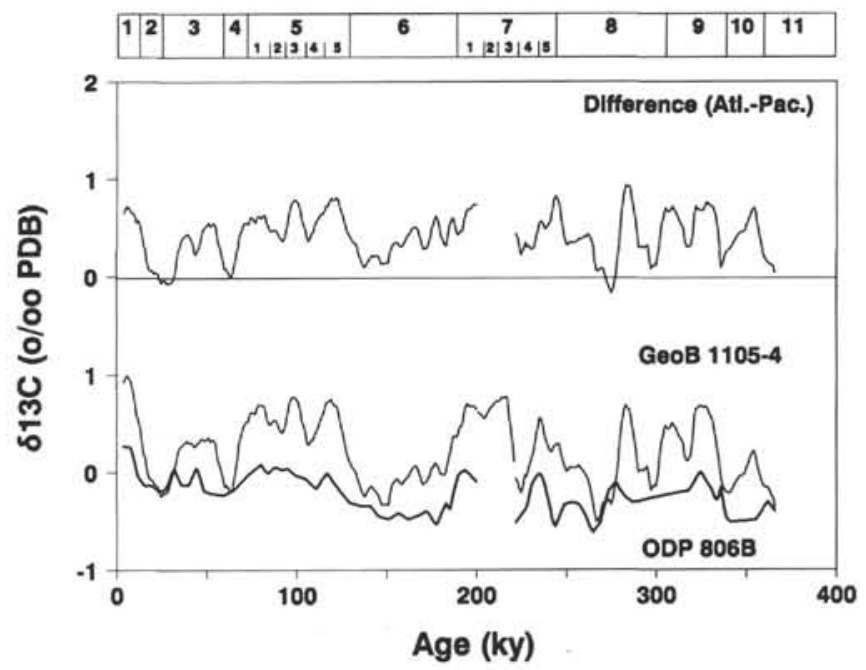

Figure 10. Comparison between Pacific (Hole 806B) and Atlantic (Core GeoB $1105-4)$ benthic $\delta^{13} \mathrm{C}$ records and their difference. 


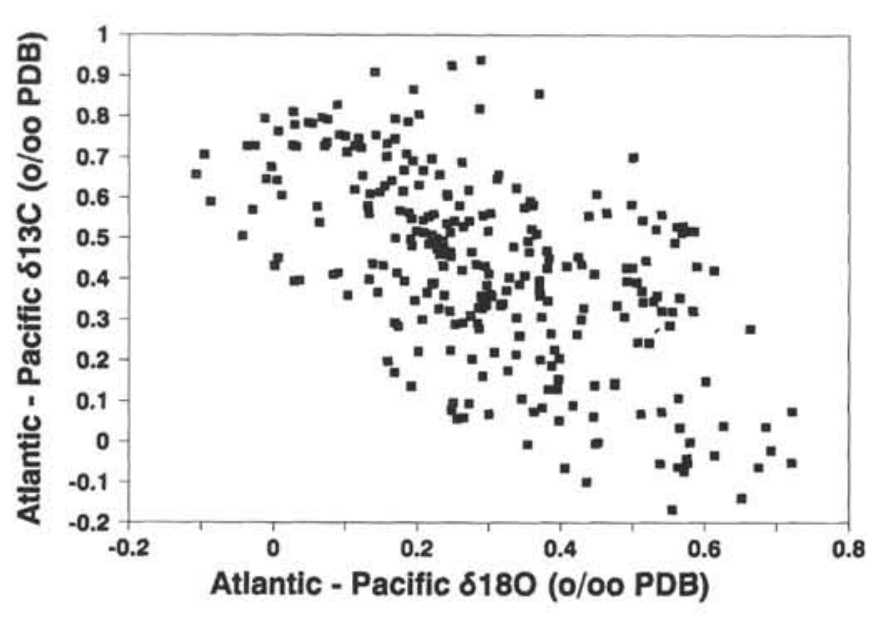

Figure 11. Covariance of deep Atlantic (Core GeoB 1105-4) and Pacific (Hole 806B) delta- $\delta^{18} \mathrm{O}$ and delta- $\delta^{13} \mathrm{C}$ values.

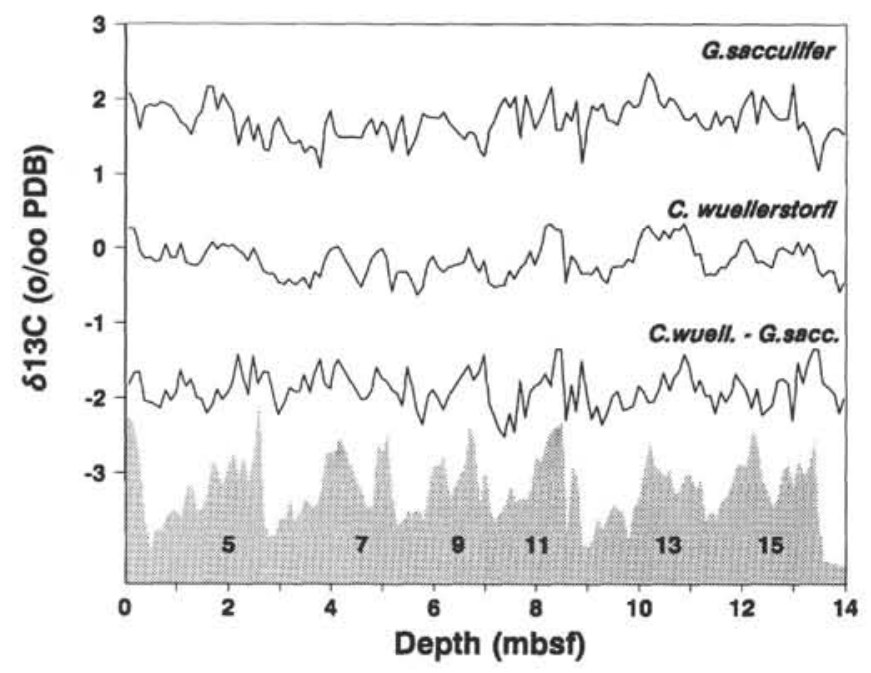

Figure 12. Hole 806B $\delta^{13} \mathrm{C}$ records for $G$. sacculifer, $C$. wuellerstorfi, and their difference.
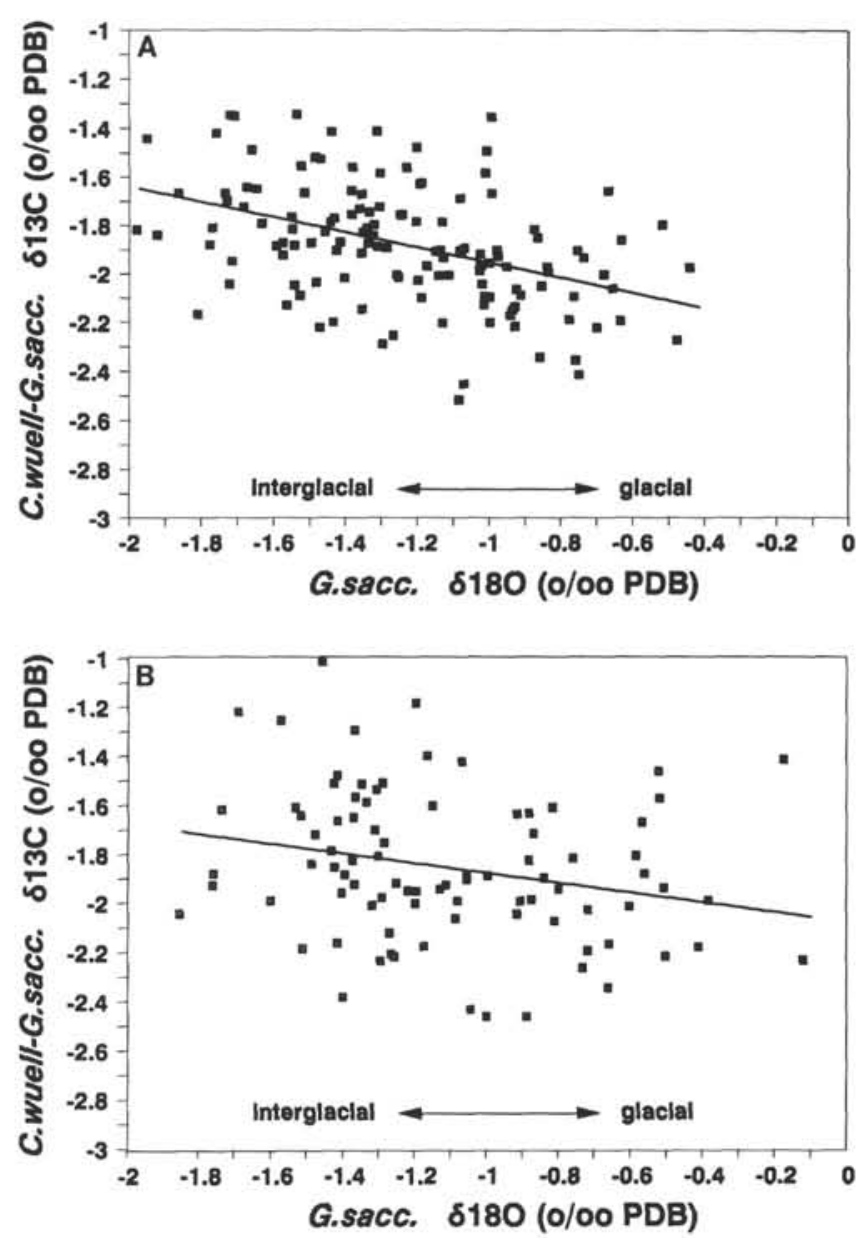

Figure 13. Covariances of $\delta^{18} \mathrm{O}$ values for $G$. sacculifer and the delta- $\delta{ }^{13} \mathrm{C}$ values for C. wuellerstorfi-G. sacculifer, Holes 806B (A) and 805C (B).

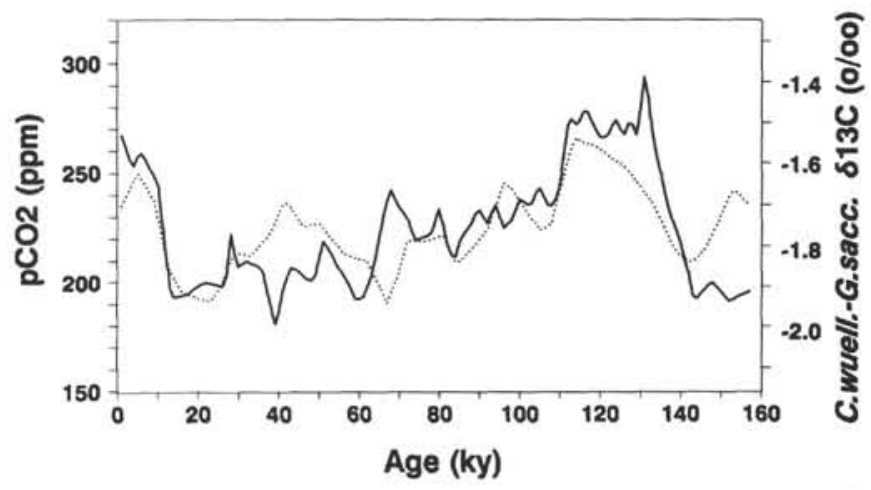

Figure 14. Comparison of the $\mathrm{pCO}_{2}$ record (Barnola et al., 1987) (solid line) and the stacked delta- $-\delta^{13} \mathrm{C}(C$. wuellerstorfi-G. sacculifer $)$ record from Holes $805 \mathrm{C}$ and $806 \mathrm{~B}$ (dotted). 
APPENDIX A

Stable Isotope Data for Holes $805 \mathrm{C}$ and 806B from Cibicidoides wuellerstorfi

\begin{tabular}{|c|c|c|c|c|c|c|c|c|}
\hline $\begin{array}{l}\text { Depth } \\
\text { (mbsf) }\end{array}$ & $\begin{array}{c}\delta^{18} \mathrm{O} \\
(\% \circ, \mathrm{PDB})\end{array}$ & $\begin{array}{c}\delta^{13} \mathrm{C} \\
(\%,, \mathrm{PDB})\end{array}$ & $\begin{array}{l}\text { Depth } \\
\text { (mbsf) }\end{array}$ & $\begin{array}{c}\delta^{18} \mathrm{O} \\
(\% \circ, \mathrm{PDB})\end{array}$ & $\begin{array}{c}\delta^{13} \mathrm{C} \\
(\% o, \mathrm{PDB})\end{array}$ & $\begin{array}{l}\text { Depth } \\
\text { (mbsf) }\end{array}$ & $\begin{array}{c}\delta^{18} \mathrm{O} \\
(\% c, \mathrm{PDB})\end{array}$ & $\begin{array}{c}\delta^{13} \mathrm{C} \\
(\% \infty, \mathrm{PDB})\end{array}$ \\
\hline \multirow[t]{2}{*}{ Hole $805 \mathrm{C}$} & & & 8.39 & 3.17 & -0.10 & 6.09 & 2.94 & -0.25 \\
\hline & & & 8.49 & 2.70 & 0.01 & 6.19 & 2.83 & -0.31 \\
\hline 0.09 & 3.06 & 0.05 & 8.59 & 2.94 & -0.22 & 6.29 & 3.40 & -0.25 \\
\hline 0.19 & 2.52 & 0.16 & 8.69 & 3.29 & -0.02 & 6.59 & 2.96 & -0.18 \\
\hline 0.29 & 3.53 & -0.08 & 8.79 & 3.47 & -0.22 & 6.69 & 2.41 & 0.01 \\
\hline 0.39 & 3.66 & 0.00 & 8.89 & 3.56 & -0.24 & 6.79 & 2.67 & -0.18 \\
\hline 0.49 & 3.69 & -0.13 & 8.99 & 3.58 & -0.30 & 6.99 & 3.00 & -0.15 \\
\hline 0.59 & 3.37 & -0.21 & 9.09 & 3.48 & -0.10 & 7.09 & 3.50 & -0.46 \\
\hline 0.69 & 3.58 & -0.18 & 9.19 & 3.22 & -0.17 & 7.19 & 3.69 & -0.51 \\
\hline 0.79 & 3.72 & -0.07 & 9.28 & 3.25 & 0.01 & 7.29 & 3.59 & -0.49 \\
\hline 0.89 & 3.52 & -0.17 & 9.39 & 3.11 & 0.05 & 7.39 & 3.47 & -0.49 \\
\hline 0.99 & 4.06 & -0.27 & 9.49 & 3.26 & -0.01 & 7.49 & 3.24 & -0.30 \\
\hline 1.09 & 3.69 & -0.32 & 9.59 & 3.84 & -0.27 & 7.59 & 3.43 & -0.40 \\
\hline 1.19 & 3.17 & 0.18 & 9.69 & 4.37 & -0.34 & 7.69 & 3.39 & -0.26 \\
\hline 1.29 & 2.52 & 0.20 & 9.79 & 4.22 & -0.34 & 7.79 & 3.39 & -0.19 \\
\hline 1.39 & 3.11 & 0.07 & & & & 7.89 & 3.28 & -0.03 \\
\hline 1.59 & 3.19 & 0.02 & Hole $806 \mathrm{~B}$ & & & 7.98 & 2.84 & -0.21 \\
\hline 1.69 & 3.14 & 0.11 & & & & 8.09 & 2.90 & -0.01 \\
\hline 1.79 & 2.42 & -0.10 & 0.09 & 2.33 & 0.27 & 8.19 & 2.60 & 0.30 \\
\hline 1.89 & 2.36 & -0.09 & 0.19 & 2.47 & 0.27 & 8.29 & 2.50 & 0.33 \\
\hline 1.99 & 4.04 & -0.34 & 0.29 & 3.01 & -0.04 & 8.39 & 2.46 & 0.26 \\
\hline 2.09 & 3.92 & -0.34 & 0.39 & 3.68 & -0.13 & 8.49 & 2.39 & 0.25 \\
\hline 2.19 & 3.74 & -0.51 & 0.49 & 4.06 & -0.13 & 8.69 & 2.98 & -0.09 \\
\hline 2.29 & 3.96 & -0.42 & 0.59 & 3.78 & -0.18 & 8.79 & 3.09 & -0.17 \\
\hline 2.39 & 3.73 & -0.49 & 0.69 & 3.82 & -0.16 & 8.89 & 4.01 & -0.33 \\
\hline 2.49 & 3.55 & -0.45 & 0.79 & 3.64 & 0.05 & 8.99 & 4.03 & -0.33 \\
\hline 2.59 & 3.56 & -0.43 & 0.89 & 3.54 & -0.12 & 9.09 & 3.93 & -0.34 \\
\hline 2.69 & 3.75 & -0.36 & 0.99 & 3.56 & -0.12 & 9.19 & 3.63 & -0.24 \\
\hline 2.79 & 3.35 & -0.01 & 1.09 & 3.63 & 0.07 & 9.29 & 3.79 & -0.40 \\
\hline 2.89 & 2,97 & -0.08 & 1.19 & 3.29 & -0.19 & 9.39 & 3.61 & -0.46 \\
\hline 2.98 & 2.92 & 0.06 & 1.29 & 3.21 & -0.21 & 9.48 & 3.47 & -0.25 \\
\hline 3.09 & 3.26 & -0.39 & 1.39 & 3.55 & -0.23 & 9.59 & 3.51 & -0.23 \\
\hline 3.19 & 3.32 & -0.51 & 1.48 & 3.55 & -0.17 & 9.69 & 3.56 & -0.23 \\
\hline 3.29 & 3.65 & -0.07 & 1.59 & 3.32 & -0.02 & 9.79 & 3.97 & -0.14 \\
\hline 3.39 & 3.35 & -0.20 & 1.69 & 2.87 & 0.08 & 9.89 & 3.50 & -0.18 \\
\hline 3.49 & 3.22 & -0.19 & 1.79 & 3.05 & -0.01 & 9.99 & 3.38 & 0.11 \\
\hline 3.59 & 3.40 & -0.33 & 1.89 & 3.23 & 0.06 & 10.09 & 2.99 & 0.27 \\
\hline 3.69 & 3.79 & -0.32 & 1.99 & 2.97 & 0.03 & 10.19 & 2.64 & 0.31 \\
\hline 3.79 & 3.65 & -0.28 & 2.09 & 2.78 & 0.04 & 10.29 & 2.93 & 0.20 \\
\hline 3.89 & 3.56 & -0.66 & 2.19 & 3.10 & -0.02 & 10.39 & 3.00 & 0.11 \\
\hline 3.99 & 3.68 & -0.62 & 2.29 & 2.83 & -0.06 & 10.49 & 3.11 & 0.25 \\
\hline 4.09 & 3.82 & -0.50 & 2.39 & 3.17 & -0.16 & 10.59 & 3.01 & 0.14 \\
\hline 4.19 & 3.05 & -0.18 & 2.49 & 2.81 & 0.00 & 10.69 & 3.34 & 0.27 \\
\hline 4.29 & 3,27 & -0.39 & 2.58 & 2.08 & -0.14 & 10.79 & 3.25 & 0.26 \\
\hline 4.39 & 3.47 & -0.36 & 2.69 & 3.76 & -0.30 & 10.89 & 3.11 & 0.34 \\
\hline 4.48 & 3.06 & 0.13 & 2.79 & 3.86 & -0.34 & 10.98 & 3.06 & 0.18 \\
\hline 4.59 & 3.20 & -0.02 & 2.89 & 3.91 & -0.33 & 11.09 & 3.28 & -0.08 \\
\hline 4.69 & 3.59 & -0.20 & 2.98 & 3.65 & -0.45 & 11.19 & 3.13 & -0.07 \\
\hline 4.79 & 2.86 & -0.03 & 3.09 & 3.66 & -0.47 & 11.29 & 3.69 & -0.36 \\
\hline 4.89 & 2.60 & 0.01 & 3.19 & 3.42 & -0.41 & 11.39 & 3.55 & -0.33 \\
\hline 4.99 & 2.35 & -0.17 & 3.29 & 3.69 & $-0,48$ & 11.49 & 3.65 & -0.35 \\
\hline 5.09 & 4.21 & -0.45 & 3.39 & 3.55 & -0.44 & 11.59 & 3.42 & -0.24 \\
\hline 5.19 & 3.63 & -0.48 & 3.49 & 3.39 & -0.39 & 11.69 & 3.35 & -0.25 \\
\hline 5.29 & 4.01 & -0.44 & 3.59 & 3.47 & -0.54 & 11.79 & 3.19 & -0.12 \\
\hline 5.49 & 3.74 & -0.52 & 3.69 & 3.50 & -0.32 & 11.89 & 2.96 & -0.09 \\
\hline 5.59 & 3.68 & -0.41 & 3.79 & 3.30 & -0.38 & 11.99 & 2.94 & 0.10 \\
\hline 6.09 & 2.41 & 0.33 & 3.89 & 2.79 & -0.15 & 12.08 & 2.95 & 0.12 \\
\hline 6.19 & 2.39 & 0.26 & 3.99 & 2.79 & -0.01 & 12.19 & 2.47 & -0.01 \\
\hline 6.29 & 2.70 & 0.18 & 4.08 & 2.75 & 0.02 & 12.29 & 2.68 & -0.18 \\
\hline 6.39 & 3.43 & -0.34 & 4.14 & 2.56 & 0.03 & 12.39 & 3.16 & -0.16 \\
\hline 6.49 & 3.84 & -0.34 & 4.59 & 3.32 & -0.51 & 12.59 & 3.49 & -0.25 \\
\hline 6.59 & 4.29 & -0.40 & 4.69 & 3.51 & -0.35 & 12.69 & 3.34 & -0.01 \\
\hline 6.69 & 4.14 & -0.37 & 4.79 & 3.50 & -0.14 & 12.79 & 3.03 & 0.02 \\
\hline 6.79 & 4.08 & -0.30 & 4.89 & 2.71 & -0.05 & 12.89 & 2.96 & -0.02 \\
\hline 6.89 & 3.82 & -0.52 & 4.99 & 2.78 & -0.00 & 12.99 & 3.21 & -0.07 \\
\hline 6.99 & 3.83 & -0.29 & 5.09 & 2.54 & -0.12 & 13.09 & 2.85 & 0.09 \\
\hline 7.09 & 3.81 & -0.30 & 5.19 & 3.38 & -0.57 & 13.19 & 3.09 & -0.09 \\
\hline 7.19 & 3.74 & -0.22 & 5.29 & 3.73 & -0.32 & 13.29 & 2.98 & 0.07 \\
\hline 7.29 & 3.72 & -0.16 & 5.39 & 3.67 & -0.31 & 13.39 & 2.61 & -0.03 \\
\hline 7.48 & 3.91 & -0.33 & 5.49 & 3.56 & -0.32 & 13.49 & 3.78 & -0.29 \\
\hline 7.89 & 3.74 & -0.35 & 5.58 & 3.61 & -0.42 & 13.58 & 4.19 & -0.37 \\
\hline 7.99 & 3.31 & -0.23 & 5.68 & 3.52 & -0.62 & 13.69 & 3.64 & -0.29 \\
\hline 8.09 & 3.09 & 0.04 & 5.79 & 3.65 & -0.52 & 13.79 & 4.14 & -0.29 \\
\hline 8.19 & 3.29 & -0.19 & 5.89 & 3.28 & -0.19 & 13.89 & 3.92 & -0.58 \\
\hline 8.29 & 2.82 & 0.08 & 5.98 & 2.97 & -0.10 & 13.98 & 3.72 & -0.46 \\
\hline
\end{tabular}


APPENDIX B

Age Control Points for Holes 805C and 806B from Peak Correlation to Stacked Isotope Record of Imbrie et al. (1984)

\begin{tabular}{|c|c|c|c|}
\hline \multicolumn{2}{|c|}{ Hole $805 \mathrm{C}$} & \multicolumn{2}{|c|}{ Hole 806B } \\
\hline $\begin{array}{l}\text { Depth } \\
\text { (mbsf) }\end{array}$ & $\begin{array}{l}\text { Age } \\
\text { (k.y.) }\end{array}$ & $\begin{array}{l}\text { Depth } \\
\text { (mbsf) }\end{array}$ & $\begin{array}{l}\text { Age } \\
(k . y .)\end{array}$ \\
\hline 0.00 & 0 & 0.00 & 0 \\
\hline 0.28 & 12 & 0.32 & 12 \\
\hline 0.88 & 53 & 0.50 & 19 \\
\hline 1.00 & 65 & 1.26 & 53 \\
\hline 1.30 & 80 & 1.42 & 65 \\
\hline 1.84 & 122 & 1.72 & 80 \\
\hline 2.02 & 135 & 2.20 & 99 \\
\hline 2.68 & 183 & 2.58 & 122 \\
\hline 2.94 & 194 & 2.73 & 135 \\
\hline 3.30 & 228 & 3.66 & 183 \\
\hline 3.48 & 238 & 3.92 & 194 \\
\hline 3.70 & 249 & 4.74 & 228 \\
\hline 4.06 & 269 & 5.00 & 238 \\
\hline 4.22 & 287 & 5.34 & 249 \\
\hline 4.36 & 299 & 5.80 & 269 \\
\hline 4.96 & 331 & 6.16 & 287 \\
\hline 5.10 & 341 & 6.34 & 299 \\
\hline 5.52 & 362 & 6.68 & 331 \\
\hline 6.16 & 405 & 6.92 & 341 \\
\hline 6.60 & 434 & 7.50 & 362 \\
\hline 7.48 & 471 & 8.36 & 405 \\
\hline 7.94 & 538 & 9.00 & 434 \\
\hline 8.50 & 574 & 9.76 & 471 \\
\hline 8.98 & 585 & 10.20 & 491 \\
\hline 9.40 & 617 & 10.74 & 513 \\
\hline \multirow[t]{5}{*}{9.79} & 628 & 11.42 & 552 \\
\hline & & 12.24 & 574 \\
\hline & & 12.52 & 585 \\
\hline & & 13.32 & 617 \\
\hline & & 13.60 & 628 \\
\hline
\end{tabular}

